\title{
Maturation evolution of chardonnay grape for juice preparation
}

\author{
Angelica Bender ${ }^{1}$, Vagner Brasil Costa ${ }^{2}$, Vinícius Caliari ${ }^{3}$, and Marcelo Barbosa Malgarim ${ }^{4}$ \\ ${ }^{1}$ Master, Federal University of Pelotas, Brazil \\ ${ }^{2} \mathrm{PhD}$, Federal University of Pampa, Brazil \\ ${ }^{3} \mathrm{PhD}$, Agricultural Research Corporation and Rural Extension of Santa Catarina, Brazil, University of West of Santa Catarina, Unoesc, \\ Brazil \\ ${ }^{4} \mathrm{PhD}$, Federal University of Pelotas, Brazil
}

\begin{abstract}
This study aims to evaluate the evolution of the maturation of the "Chardonnay" grape variety for the preparation of juices and its adequacy to the current legislation. Grapes from the 2015 harvest from São Lourenço do Sul-RS were used. The experimental design was completely randomized in a factorial design, with the treatment factor being the maturation stages. The physicochemical analysis of titratable acidity, soluble solids, relative density, total sugar, alcohol content, volatile acidity and SS/TA ratio were carried out in EPAGRI - Agricultural Research and Rural Extension Company of Santa Catarina, in the Videira Experimental Station (Videira SC/Brazil). Statistical analysis of the maturation stages was given by linear regression models. When comparing the maturation points of $17^{\circ}$ Brix and $19^{\circ}$ Brix to $15^{\circ}$ Brix, volatile acidity and alcohol content did not fit to the model, while the other tested variables fit properly. Elaborated juices had a decrease in titratable acidity and percentage increments for soluble solids, SS/TA ratio and total sugars for the harvest points at 17 and $19^{\circ}$ Brix. For $15^{\circ}$ Brix and $17^{\circ}$ Brix, nonconformity was observed with the identity and quality standards in relation to soluble solids and SS/TA ratio and relative density. At maturation point $19^{\circ}$ Brix all variables were found to be consistent.
\end{abstract}

\section{Introduction}

Grape juice is an unfermented drink that may be classified as concentrated, reprocessed or reconstituted, dehydrated, whole and sweetened grape juice. The whole grape juice classification refers to the juice obtained by means of suitable technological processes without the addition of sugars and in its natural constitution [1,2].

Grape juice has increasingly gained more space in the market, not only for its sensory characteristics, but also for its antioxidant properties, which act in the prevention of various types of diseases [3]. The various types of grape juice produced in Brazil offer significant amounts of phenolic compounds, especially for people who do not consume grape-derived alcohol [4].

Some factors such as climate, grape cultivar, soil, among others, can influence the physicochemical composition and the amount of phenolic compounds in grapes and therefore the juice [3].

In Brazil, grape juice is mainly elaborated from Vitis labrusca grapes, due to their aroma and fruity and foxy flavors. In many countries of Central Europe, the juice is made from Vitis vinifera grapes, from both white and red cultivars. The juice yield, freshness after processing, sanitation and adequate grape maturity are factors that influence the choice of the variety [5].

In general, the more mature grapes favor obtaining better quality juice, as well as higher sugar content, since they have lower acidity, and hence higher sugar/acid ratio [6].

Grape is not a climacteric fruit, so it is crucial that the harvest occur at the moment of maximum expression of its quality potential in a certain crop or region. The optimum maturation for harvest is found through the appearance, consistency, and especially the sugar content in the must. Thus, it becomes necessary to perform the monitoring of maturation by sensory and chemical analysis of representative samples of the vineyard every two or three days $[6,7]$.

The behavior of grapevines is different each season, and in each region or vineyard due to local environmental conditions. Weather conditions such as temperature, humidity and solar radiation exert great influence on the development, production and quality of grapes intended for processing. These variables lead to changes in the chemical composition and kinetics of grape maturation, in the evolution of the vineyards and the estimated date of harvest [8]. It is ideal to harvest the grapes according to their maturation and not due to phytosanitary problems caused especially by the bunch rot [9]. At the end of the maturation period, temperatures close to $30^{\circ} \mathrm{C}$ are required so that grape acidity is not very high [10].

Rainy years especially during the ripening period end up weakening the grape quality, making it unsatisfactory for winemaking. The possibility of using wine varieties in the preparation of juices is presented as an alternative to crops in which the grapes do not reach ideal harvest point for winemaking.

Assuming that the preparation of juice from wine grapes can be an alternative to use these during harvests considered poor for winemaking, and can be harvested in advance, thus preventing losses from late cycle disease and excessive spending on phytosanitary treatments, this work aimed to evaluate the evolution of the maturation of 
"Chardonnay" grapes for the preparation of juices and their adequacy to current legislation.

\section{Materials and methods}

The grapes used as raw material for the preparation of juices were of European variety (Vitis vinifera): Chardonnay 2015 crop, grown in commercial orchard located in São Lourenço do Sul $\left(31^{\circ} 21^{\prime \prime} 54^{\prime \prime} \mathrm{S}, 51^{\circ}\right.$ $58^{\prime \prime} 40^{\prime \prime} \mathrm{W}, 26 \mathrm{~m}$ altitude). The region climate is Cfa type, seasoned with hot, humid summers and very cold winters [11]. The soil is classified as Bruno-Grey and RedYellow Argisols and Litholic and Regolitic Neosols and elevation composed of plateaus and plains [12].

The municipality of São Lourenço does not have a weather station, thus data from the neighbor city of Pelotas was used, since it belongs to the micro-region of this municipality. Minimum and maximum temperature and rainfall data of the city of Pelotas, for the duration of the experiments were obtained from the meteorology laboratory of Embrapa Temperate Climate [13]. The average minimum temperature was $20.2^{\circ} \mathrm{C}$, the maximum average was $27.4^{\circ} \mathrm{C}$ and the total precipitation was $168.8 \mathrm{~mm}$ for the month of January/2015. For the month of February/2015, the average minimum temperature was $20.8^{\circ} \mathrm{C}$, the maximum average was $25.6^{\circ} \mathrm{C}$ and the total precipitation was $407.4 \mathrm{~mm}$.

\subsection{Monitoring the maturation and harvest of the grapes}

90 plants were selected, arranged in three different rows to run the experiment. The plants were conducted in espalier system under rootstock Paulsen 1103, pruned in cordon, spaced two meters between plants and 3 meters between rows. The handling and treatment of crops was carried out following the technical recommendations of the culture. The harvest was conducted manually, differing dates between the points of harvest during the months of January and February 2015 (Fig. 1).

Approximately 20 kilos were allocated to prepare the juice in each point of harvest, previously determined, according to the soluble solids content, being 15, 17 and $19^{\circ}$ Brix.

Monitoring of the phenology of the vine production cycle was carried out from the period of pruning until harvest, through visual observations made by visits to the vineyard, every five days until the start of maturation, and later on at 3 day intervals. The phenological characterization was performed on 20 plants, randomly selected, which were used for evaluations following the Eichhorn and Lorenz phenological scale system [14].

\subsection{Juice preparation}

The juices were elaborated in the Postharvest Laboratory of the Federal University of Pelotas (Pelotas, RS/Brazil). The extraction of the must occurred with juice extractor or extraction pan with a capacity of $20 \mathrm{~kg}$ of fruit. Initially the berries were removed and selected manually, excluding damaged and unripe ones. Later they were placed in perforated container, which was fitted to an outer container, and both coupled to the water tank,

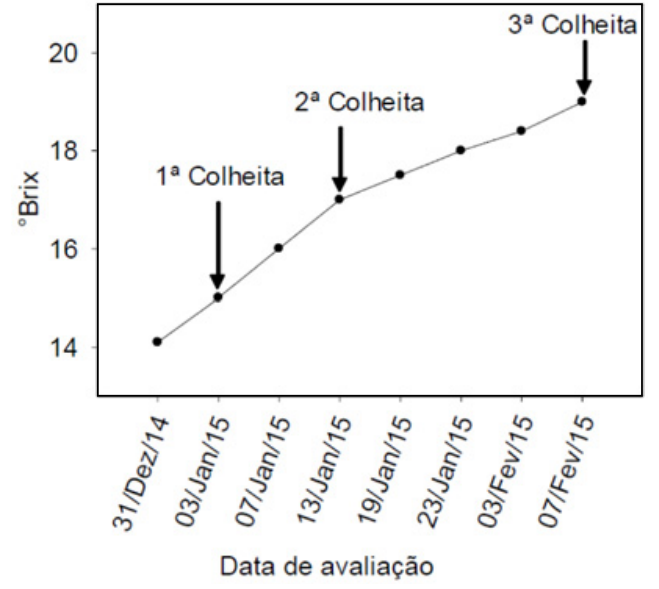

Figure 1. Monitoring the maturation of the berries of the Chardonnay variety for the definition of maturation stages. (1st harvest: $15^{\circ}$ Brix; 2 nd harvest: $17^{\circ}$ Brix, 3rd harvest: $19^{\circ}$ Brix). UFPel, Pelotas, 2015/16.

which was settled on gas stove for heat generation. After approximately 20 minutes the must began to flow through the outlet tube, which is replaced above the grape until a temperature of $85^{\circ} \mathrm{C}$.

The bottling of the samples took about an hour and thirty minutes, controlling the temperature inside the bottle with the help of thermometer (Incoterm, -10 to $100^{\circ} \mathrm{C}$ ), discarding the first and last portion of the extracted juice. 1.5-liter glass bottles were used, previously sanitized with chlorinated water and subsequently left in boiling water until the time of bottling. Immediately after bottling, the bottles were sealed with plastic screw cap, being held with the neck down. The samples were kept under refrigeration until the time of analysis.

The experimental design was completely randomized with three replications. The treatments were arranged in a unifactorial scheme. The treatment factor was the maturation stages $\left(15,17\right.$ and $19^{\circ}$ Brix $) .3$ bottles were used for each variety, in each sampling point where each bottle represented a repetition, and submitted for physicochemical analysis.

\subsection{Physicochemical analysis}

The physicochemical analysis of titratable acidity, soluble solids, relative density, total sugar, alcohol, volatile acidity and SS/TA ratio, were held in the Epagri Station Agricultural Research Corporation and Rural Extension of Santa Catarina, Videira Experimental Station (Videira, SC/ Brazil).

Analyses were performed according to the methodology of the Ministry of Agriculture [15].

For determination of titratable acidity (TA), $10 \mathrm{ml}$ juice was homogenized in $100 \mathrm{ml}$ of distilled water, added with 2-3 drops of phenolphthalein, this dilution was titrated with $\mathrm{NaOH}$ solution $(0.1 \mathrm{~N})$ until reaching the pink color (turning point) and the results are expressed in g100g1 tartaric acid.

The results of soluble solids (SS) were expressed in ${ }^{\circ}$ Brix, the relative density in $\mathrm{cm} 3$, total sugars in g.100g1 , alcohol content in $\mathrm{v} / \mathrm{v}$ and volatile acidity expressed in g. $100 \mathrm{~g}-1$ acetic acid were determined by an electronic enological distiller (Gibertini $R$ ), which is calibrated with 


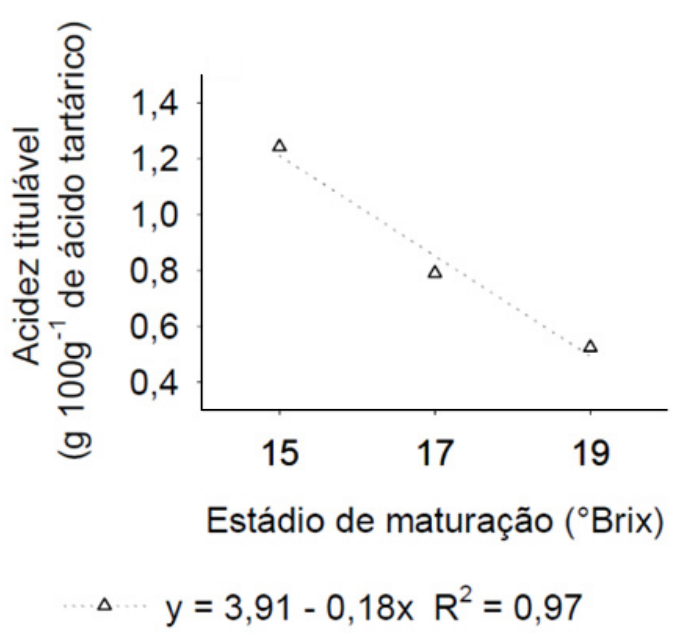

Figure 2. Titratable acidity (g 100g-1 tartaric acid) of the juice from Chardonnay $(\mathrm{CH})$ grape variety along three stages of maturation. UFPel, Pelotas, 2015/16.

distilled water before adding the samples, and obtaining the readings.

The TS/TA ratio was obtained from the quotient of the soluble solids and titratable acidity.

\subsection{Statistical analysis}

Data were analyzed for normality by the ShapiroWilk test; homoscedasticity by the Hartley test; and the independence of the residues by graphical analysis. Later, the data were submitted to analysis of variance by $F$ test $(p \leq 0.05)$. Noting a statistical significance, the effects of maturation stages were compared by linear regression models $(\mathrm{p} \leq 0.05): y=y o+a x$, where: $y=$ response variable; $y o=$ variable response corresponding to the minimum or maximum point of the curve; $a=$ slope of the line or curve; $x=$ degrees in ${ }^{\circ}$ Brix. The model selection was based on: (a) low residue; (b) low $p$-value; and (c) high R2 and R2 adj.

\section{Results and discussions}

The assumptions of the mathematical model were all met and did not require the processing of data for all variables. Analyses of titratable acidity $(\mathrm{F}=12.41, \mathrm{p}<0.0001)$, total soluble solids $(\mathrm{F}=6.52, \mathrm{p}=0.0020), \mathrm{SS} / \mathrm{TA}$ ratio $(\mathrm{F}=15.18, \mathrm{p}<0.0001)$, relative density $(\mathrm{F}=7.04$, $\mathrm{p}=0.0014)$, total sugars $(\mathrm{F}=10.37, \mathrm{p}=0.0002)$ showed significance for the interaction between the tested treatment factors. For the variables alcohol $(\mathrm{F}=0.49$, $\mathrm{p}=0.6204)$ and volatile acidity $(\mathrm{F}=5.55, \mathrm{p}=0.0048)$ there was no significance to the maturation stage.

Titratable acidity is regulated by law, which establishes a minimum of $0.41 \mathrm{~g} 100 \mathrm{~g}-1$ in tartaric acid, the values obtained in the juices for the three sampling points were $1.24,0.59,0.58 \mathrm{~g} .100 \mathrm{~g}-1$ tartaric acid, all juices met the requirement at the different points of maturation [1].

The titratable acidity data fit properly to the linear regression model $(\mathrm{F}=253.2303, \mathrm{p}<0.0001)$ (Fig. 2). Percentage decrease in titratable acidity values of 29.7 and $59.5 \%$ for $17^{\circ}$ Brix and $19^{\circ}$ Brix, were observed respectively, in relation to $15^{\circ}$ Brix.

The decrease of the concentration of organic acids during the course of maturation is due to dilution of

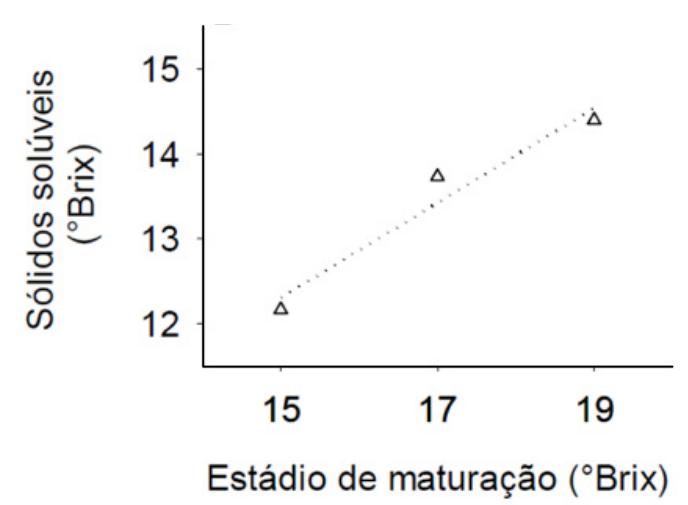

$$
\cdots \Delta \cdots y=3,94+0,56 x R^{2}=0,82
$$

Figure 3. Soluble Solids ( ${ }^{\circ}$ Brix) of the juice from Chardonnay $(\mathrm{CH})$ grape variety along three stages of maturation. UFPel, Pelotas, 2015/16.

the must by water entry, transported in the xylem by the mobilization of bases which neutralize the organic acids and by the breathing process [16]. The breathing phenomenon is influenced by temperature and rainfall, characterizing less acidic grapes in years of hot and dry summers [17]. The increase of the averages observed over the different sampling points, may be related to higher temperature and lower rainfall during the month of January (Fig. 1), a period that coincided with most of the harvest.

For soluble solids, the data fit properly to the linear regression model $(\mathrm{F}=31.2046, \mathrm{p}=0.0008)$ (Fig. 3). Increases were observed in soluble solids content being $9 \%$ and $18.2 \%$ for 17 and $19^{\circ}$ Brix respectively, compared to $15^{\circ}$ Brix.

The soluble solids content in whole grape juice must be at least $14.0^{\circ}$ Brix [1]. At the point of $15^{\circ}$ Brix $\left(12.1^{\circ}\right.$ Brix $)$ and $17^{\circ}$ Brix $\left(13.7^{\circ}\right.$ Brix), the analyzed juices did not meet the legislation specification. As for $19^{\circ}$ Brix (14.4 $4^{\circ}$ Brix), the average was consistent with the standards of identity and quality for the soluble solids variable.

Like titratable acidity, soluble solids content is influenced by climatic factors. When high temperatures and insolation are predominant, the vine metabolism favors a greater accumulation of soluble solids in the grape berries [18]. The juice preparation method may have an influence on the difference observed in the value of soluble solids of the grape in relation to the juice. These variations may be due to dilution caused by the incorporation of water generated by the steam used during heating for the extraction of the coloring of the berries [19].

Other researchers have found higher values for juices prepared from "C. Sauvignon" and "Tempranillo", 15.4 and $16.4^{\circ}$ Brix, respectively, but under the same study, "Syrah" juice showed a lower value of $13^{\circ}$ Brix. The authors attributed the findings to the possible dilution caused by the production method [20].

The data of SS/TA ratio fit properly to the linear regression model $(\mathrm{F}=236.3966, \mathrm{p}<0.0001)$ (Fig. 4). Increases were observed when comparing the $17^{\circ}$ Brix and $19^{\circ}$ Brix maturation points to the $15^{\circ}$ Brix, the percentages were $95.2 \%$ and $190.4 \%$, respectively.

The value obtained for the SS/TA ratio at harvest point $15^{\circ}$ Brix (9.79) was below the limit established by law, which is between 15 to 45 [1]. At harvest points 


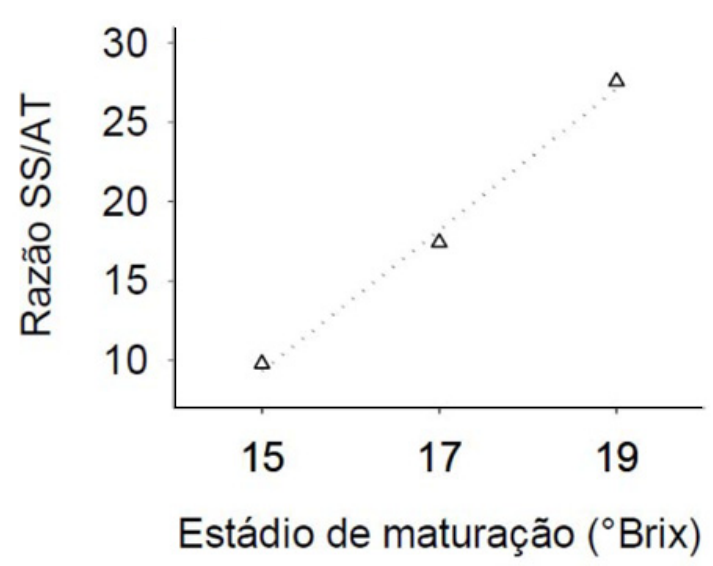

$$
\Delta \cdots y=-57,27+4,44 x R^{2}=0,97
$$

Figure 4. SS/TA ratio of the juice from Chardonnay $(\mathrm{CH})$ grape variety along three stages of maturation. UFPel, Pelotas, 2015/16.

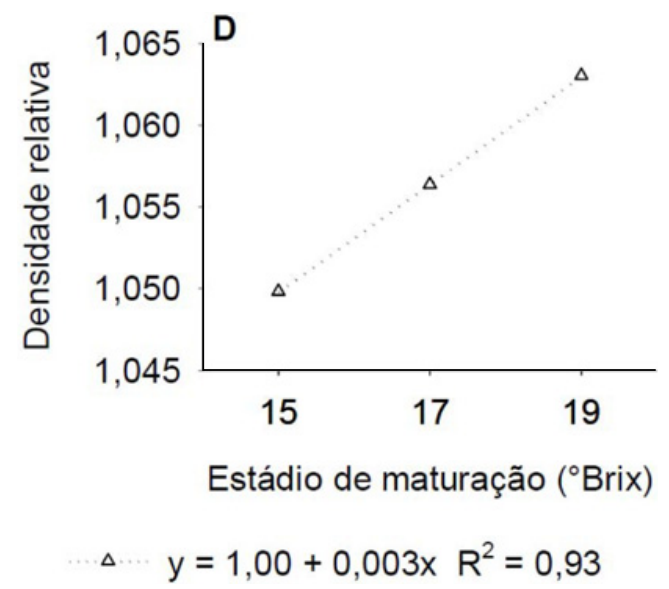

Figure 5. Relative density (g.cm3) of the juice from Chardonnay (CH) grape variety along three stages of maturation. UFPel, Pelotas, 2015/16.

$17^{\circ}$ Brix (17.4) and $19^{\circ}$ Brix (27.5), the juices were within limits established by the law for the SS/TA ratio variable. However, at $17^{\circ}$ Brix, the value was very close to the established minimum showing that these juices have a considerable acidity, being below that considered ideal by other authors, who state that the SS/TA ratio must be equal to or greater than 20 [21].

The relative density of the grape juice should be at least 1,057 g.cm3 [1]. At $15^{\circ}$ Brix (1.049 g.cm3), the "Chardonnay" juice showed values lower than those set by law, at $17^{\circ}$ Brix (1.059 g.cm3) and $19^{\circ}$ Brix (1.060 g.cm3) the behavior was reversed, the juices remained above the minimum required. The relative density data fit appropriately to the linear regression model $(\mathrm{F}=96.1785$, $\mathrm{p}<0.0001$ ) (Fig. 5).

When comparing the maturation of points at 17 and $19^{\circ}$ Brix to $15^{\circ}$ Brix, increases of $0.6 \%$ and $1.2 \%$ were observed respectively. Similar to the soluble solids content, density had a significant linear increase, because it is directly related to the concentration of sugars in the must and may suffer dilution by water vapor used in the extraction method.

For total sugars, Brazilian legislation establishes a maximum value for $20 \mathrm{~g} .100 \mathrm{~g}-1$ [1]. The prepared juices

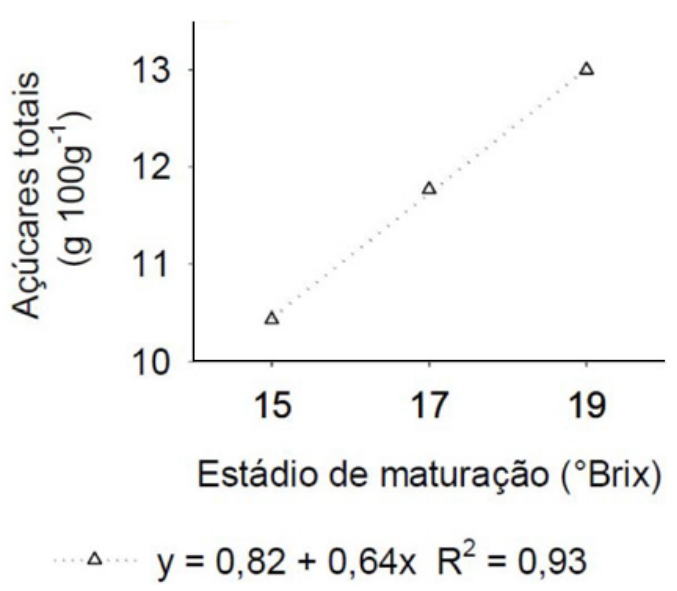

Figure 6. Total sugars (g 100g-1) of the juice from Chardonnay $(\mathrm{CH})$ grape variety along three stages of maturation. UFPel, Pelotas, 2015/16.

were within the established limit for the three points of maturation $10.43 \mathrm{~g} .100 \mathrm{~g}-1,11.77 \mathrm{~g} .100 \mathrm{~g}-1$ and 13 g. $100 \mathrm{~g}-1$, respectively for 15,17 and $19^{\circ}$ Brix.

The total sugars data fit properly to the linear regression model $(\mathrm{F}=88.8715, \mathrm{p}<0.0001)$ (Fig. 6). Increases of $12.3 \%$ and $24.6 \%$ were observed in total sugar values for 17 and $19^{\circ}$ Brix, respectively, compared to $15^{\circ}$ Brix.

The total sugars in the whole juice are derived exclusively from grapes that gave rise to it. In general, Vitis vinifera cultivars have a greater potential of producing sugars than the American grapes Vitis labrusca [22,23]. Sugars produced in grapes vary among cultivars and environmental conditions [24]. The sanitary condition of the grapevine, especially diseases that attack the leaves, causing premature defoliation leads to a lower accumulation of sugars in the grapes, since most of these comes from the leaves in the form of sucrose and is then converted into fructose and glucose in the berries [24].

Increases in total sugar content were observed in the harvest points of 17 and $19^{\circ}$ Brix in relation to point $15^{\circ}$ Brix. Confronting the average of the three harvest points, one can see that this increase was relatively small. These results may reflect the severe attack of mildew that led to the premature loss of leaves, this occurred between late January and early February, coinciding with the maturation period of the grapes, which reflected a low level of accumulated sugars in berries.

The volatile acidity and alcohol values were within the limits established by Brazilian legislation, which is $0.50 \mathrm{~g} 100 \mathrm{~g}-1$ acetic acid and $0.5 \% \mathrm{v} / \mathrm{v}$, respectively [1]. The values for volatile acidity and alcohol at $15^{\circ}$ Brix and $17^{\circ}$ Brix were $0.01 \mathrm{~g} 100 \mathrm{~g}-1$ acetic acid and $0.1 \% \mathrm{v} / \mathrm{v}$ respectively, for $19^{\circ} \mathrm{Brix}$ the values were $0.009 \mathrm{~g} 100 \mathrm{~g}-1$ acetic acid and $0.1 \% \mathrm{v} / \mathrm{v}$.

\section{Conclusions}

There was a linear evolution in the maturation of the grapes of the variety "Chardonnay" over the three harvest points, a determining factor in the adequacy of juices to current legislation.

At harvest points $15^{\circ}$ Brix and $17^{\circ}$ Brix, nonconformity was observed with the identity and quality standards in 
relation to soluble solids and SS/TA ratio and relative density. At maturation point $19^{\circ}$ Brix all variables were found to be consistent.

\section{References}

[1] BRASIL, Ministério da Saúde. Secretaria de Vigilância Sanitária. Portaria $\mathrm{N}^{\circ} 55$, de 27 de julho de 2004. Complementação dos padrões de identidade e qualidade do vinho e dos derivados da uva e do vinho. Diário Oficial da União. Brasília, 30 de julho de 2004, Seção 1, p. 4 (2004)

[2] BRASIL, Decreto $\mathrm{n}^{\circ} 8.198$, de 20 de fevereiro de 2014. Regulamenta a Lei $\mathrm{n}^{\circ} 7.678$, de 8 de novembro de 1988, que dispõe sobre a produção, circulação e comercialização do vinho e derivados da uva e do vinho. Diário Oficial da União. Brasília, 20 de fevereiro de 2014, Seção 3, p. 8 (2014)

[3] A. C. V. Boas, Caracterização físico-química, sensorial e avaliação da atividade antioxidante de sucos de uva e blends produzidos no sudoeste de Minas Gerais, Lavras, Universidade Federal de Lavras (Dissertação de mestrado), 116 p. (2014)

[4] C.K. Sautter; S. Denardin; A.O. Alves; C.A. Mallmann; N.G Penna; L.H., Hecktheuer, Determinação de resveratrol em sucos e uva no Brasil. Ciência e Tecnologia de Alimentos, Campinas, v. 25, n. 3, p. 437-442 (2005)

[5] V. Marzarotto, Suco de uva. In: Venturini Filho, W. G. Bebidas não alcoólicas. São Paulo: Edgard Blücher,. v. 2. cap. 19, p. 359-385 (2010)

[6] L. A. Rizzon; V. Manfroi; J. Meneguzzo, Elaboração de suco de uva na propriedade vitivinícola, Bento Gonçalves, Embrapa Uva e Vinho. Circular Técnica n' 21. 22 p. (1998)

[7] A.D.T. Sachi; L.A. Biasi, Maturação de quatro cultivares de uvas muscadíneas em Pinhais, PN. Scientia Agraria, Curitiba, v. 9, n. 2, p. 255-260 (2008)

[8] P. Ribéreau-gayon; P. Glories; A. Maujean; Y. Dubourdieu, Tratado de Enología: química del vino estabilización y tratamientos. $1^{\mathrm{a}}$. Ed. Buenos Aires: Hemisfério Sur, v. 2, 537p. (2003)

[9] C.G. Guerra; F. Mandelli; J. Tonietto; M.C. Zanus; U.A. Camargo, Conhecendo o essencial sobre uvas e vinhos. Bento Gonçalves: Embrapa Uva e Vinho, 69p. (2009)

[10] E. Giovannini, Produção de uvas para vinho, suco e mesa. Porto Alegre: Renascença, 362 p. (2008)

[11] W. Köppen; R. Geiger, Klimate der Erde. Gotha: Verlag Justus Perthes. Wall-map $150 \mathrm{~cm} \times 200 \mathrm{~cm}$ (1928)
[12] N.G. Cunha; R.J.C. Silveira; C.R.S. Severo, Estudo de Solos de São Lourenço do Sul-RS. Pelotas, Embrapa Clima Temperado, 47p. (2006)

[13] Embrapa. Centro Nacional de Pesquisa do Solo. Sistema brasileiro de classificação de solos. 2.ed. Rio de Janeiro, Embrapa Solos, 306p. (2006)

[14] K. W. Eichhorn; H. K. Lorenz, Phänologische Entwicklungsstadien der Rebe. Quelle: Sonderdruck Der Deutsche Weinbau, v. 1 (1977)

[15] Ministério da Agricultura. Métodos da área BEV/ IQA (2014)

[16] L. Manfroi; A. Miele; L.A. Rizzon; C.I.N. Barradas; P.V.D. Souza; Evolução da maturação da uva Cabernet Franck conduzida no sistema lira aberta. Ciência Agrotecnologia, Lavras, v. 28, n. 2, p. 306313, mar./abr. (2004)

[17] F.O.N. Tomaz, Estudo da Evolução dos Compostos da Uva ao Longo da Maturação em Clima SemiÁrido. Instituto Superior de Agronomia, Universidade Técnica de Lisboa. Lisboa, (Dissertação), 82 p. (2013)

[18] T. P. Ribeiro; M. A. C. Lima; R. E. Alves. Maturação e qualidade de uvas para suco em condições tropicais, nos primeiros ciclos de produção. Pesq. Agrop. Brasileira, Brasília, v. 47, n. 8, p. 1057-1065 (2012)

[19] L. A. Rizzon; M. Link, Composição do suco caseiro de diferentes cultivares. Ciência Rural, Santa Maria, v. 36, n. 2, p. 689-692 (2006)

[20] M.C.P. Dutra; M.S. Lima; A.P.A. Barros; R.J. Mascarenhas; A. Lafisca, Influência da variedade de uvas nas características analíticas e aceitação sensorial do suco artesanal. Ver. Brasileira de Produtos Agroindustriais, Campina Grande, v. 16, n. 3, p. 265-272 (2014)

[21] M. M. Choudhury, Uva de mesa: pós-colheita. Brasília: Embrapa Informação Tecnológica (Frutas do Brasil, 12); Petrolina-PE: Embrapa Semiárido, 55 p. (2001)

[22] S. Perez-Magarino; M.L.G.S. José, Evolution of flavanols, anthocyanins, and their derivatives during the aging of red wines elaborated from grapes harvested at different stages of ripening. Journal of Agricultural and Food Chemistry, v. 52, p. 1181-1189 (2004)

[23] G. González-neves; L. Barreiro; G. Gil; J. Franco; M. Ferrer; M. Moutounet; A. Carbonneau, Anthocyanic composition of Tannat grapes from the South Region of Uruguay. Analytica Chimica Acta, Amsterdã, v. 513, p. 197-202 (2004)

[24] E. Giovaninni; V. Manfroi, Viticultura e Enologia: Elaboração de grandes vinhos no terroirs brasileiros. Bento Gonçalves: IFRS (2009) 